\title{
Penerapan Sanksi Tindakan Terhadap Pelanggaran Lalu Lintas yang Dilakukan oleh Anak
}

\author{
Ahsanul Rauf, Nys. Arfa, Elizabeth Siregar \\ Fakultas Hukum, Universitas Jambi \\ Auhtor Email correspondence: raufjambi7@gmail.com
}

\begin{abstract}
ABSTRAK
Artikel ini bertujuan untuk mengetahui dan menganalisis penerapan sanksi tindakan terhadap pelanggaran lalu lintas yang dilakukan oleh anak di Polres Tanjung Jabung Barat dan untuk mengetahui dan menganalisis kendala penerapan sanksi tindakan terhadap pelanggaran lalu lintas yang dilakukan oleh anak di Polres Tanjung Jabung Barat. Penelitian ini merupakan tipe penelitian yuridis empiris. Hasil penelitian menunjukkan bahwa bentuk sanksi tindakan terhadap pelanggaran lalu lintas kendaraan bermotor yang dilakukan oleh anak di Polres Tanjung Jabung Barat terbagi atas 5 (lima) bentuk sanksi tindakan. Jumlah pelanggaran lalu lintas yang dikenakan sanksi tindakan tidak dipatok khusus untuk pelanggaran apa saja, bentuk sanksi yang diberikan diserahkan kepada pihak anggota Satlantas Polres Tanjabbar, tetapi pada umumnya sanksi tindakan berupa push up dan dipanggil orang tuanya dan kemudian membuat surat perjanjian atau pernyataan tidak mengulangi lagi. Kendala dalam penerapan sanksi tindakan terhadap pelanggaran lalu lintas yang dilakukan oleh anak di Polres Tanjung Jabung Barat yaitu keterbatasan sarana dan prasarana dan kedudukan keuangan untuk dialokasikan untuk penerapan sanksi tindakan ini belum dianggarkan oleh pemerintah selain penerapannya memerlukan kebijakan dan SOP yang harus dibakukan dulu melalui regulasi peraturan perundang-undangan.
\end{abstract}

\section{ARTICLE HISTORY}

Submission: 2021-03-25

Accepted: 2021-04-25

Publish: 2021-04-26

KEYWORDS: Action sanctions; children; traffic violations.
Kata Kunci: Anak; pelanggaran lalu lintas; sanksi tindakan.

\begin{abstract}
This article aims to determine and analyze the application of sanctions against traffic violations committed by children at the Tanjung Jabung Barat Police and to identify and analyze the constraints of implementing sanctions for traffic violations committed by children at the Tanjung Jabung Barat Police. This research is a type of empirical juridical research. The results showed that the form of sanctions against motor vehicle traffic violations committed by children at the Tanjung Jabung Barat Police was divided into 5 (five) forms of action sanctions. The number of traffic violations subject to action sanctions is not specifically pegged for any violations, the form of sanctions given is submitted to members of the Tanjabbar Police Traffic Unit, but generally the sanctions for action are in the form of push ups and being called by their parents and then making a letter of agreement or statement not to repeat again. Constraints in implementing sanctions for traffic violations committed by children at the Tanjung Jabung Barat Police are limited facilities and infrastructure and financial position to be allocated for the application of these sanctions that have not been budgeted for by the government besides its application requires policies and SOPs that must be standardized first through regulatory regulations. legislation.
\end{abstract}




\section{A. PENDAHULUAN}

Istilah anak mempunyai banyak arti, dikaitkan dengan manusia, anak bisa diartikan sebagai "keturunan atau orang yang masih kecil"1. B. Simanjuntak mengemukakan bahwa:

Istilah anak dipakai sebagai anonim dari kata dewasa. Ditinjau dari sudut psikologis anak memang tidak sama dengan orang dewasa. Perkembangan jiwa manusia sejak dilahirkan sampai menjadi dewasa terbagi dalam beberapa fase yang setiap fase perkembangan tersebut ditandai oleh ciri-ciri tertentu. ${ }^{2}$

Menurut Pasal 1 angka 1 Undang-Undang Nomor 35 Tahun 2014 Tentang Perubahan Atas Undang-Undang Nomor 23 Tahun 2002 Tentang Perlindungan Anak menentukan, "anak adalah seseorang yang belum berusia 18 tahun, termasuk anak yang masih dalam kandungan".

Menurut Pasal 1 angka 2, 3, 4 dan 5 Undang-Undang Nomor 11 Tahun 2012 tentang Sistem Peradilan Pidana Anak diklasifikasikan pengertian anak ke dalam halhal berikut ini:

2. Anak yang Berhadapan dengan Hukum adalah anak yang berkonflik dengan hukum, anak yang menjadi korban tindak pidana, dan anak yang menjadi saksi tindak pidana.

3. Anak yang Berkonflik dengan Hukum yang selanjutnya disebut Anak adalah anak yang telah berumur 12 (dua belas) tahun, tetapi belum berumur 18 (delapan belas) tahun yang diduga melakukan tindak pidana.

4. Anak yang Menjadi Korban Tindak Pidana yang selanjutnya disebut Anak Korban adalah anak yang belum berumur 18 (delapan belas) tahun yang mengalami penderitaan fisik, mental, dan/atau kerugian ekonomi yang disebabkan oleh tindak pidana.

5. Anak yang Menjadi Saksi Tindak Pidana yang selanjutnya disebut Anak Saksi adalah anak yang belum berumur 18 (delapan belas) tahun yang dapat memberikan keterangan guna kepentingan penyidikan, penuntutan, dan pemeriksaan di sidang pengadilan tentang suatu perkara pidana yang didengar, dilihat, dan/atau dialaminya sendiri.

Terjadinya tindak kejahatan/pelanggaran pada umumnya dan tindak pidana lalu lintas dan angkutan pada khususnya memang tidak tertutup kemungkinannya dilakukan oleh anak, khusus pada pelanggaran lalu lintas sebagai salah satunya. Kekhawatiran atau kecemasan pada masyarakat dikarenakan meningkatnya kasuspelanggaran lalu lintas khususnya yang dilakukan oleh anak. Hal ini membuat keresahan dan kenyamanan pada masyarakat.

Pelanggaran lalu lintas sangat jelas disebutkan dalam Bab XIII Undang-Undang Nomor 22 Tahun 2009 Tentang Lalu Lintas dan Angkutan Jalan yang merupakan Ketentuan hukum dari Undang-Undang tersebut. Ketentuan hukum di atas tentu sudah sangat jelas menjelaskan banyaknya dan apa saja pelanggaran Lalu Lintas. Dalam Undang-Undang Nomor 22 Tahun 2009 Tentang Lalu Lintas dan Angkutan jalan halhal mengenai tindak pidana lalu lintas terdapat sebanyak 44 Pasal, yang diatur dalam Bab XX. Ketentuan pidana mulai dari Pasal 273 hingga Pasal 317 UULAJ.

1 Tim Penyusun Kementerian Pendidikan dan Kebudayaan, Kamus Besar Bahasa Indonesia, Balai Pustaka, Jakarta, 2008. hlm. 30.

2 B. Simandjuntak, Latar Belakang Kenakalan Remaja, Alumni, Bandung, 2011. hlm. 51. 
Pelanggaran lalu lintas di Kabupaten Tanjung Jabung Barat tidak terlepas dari pelanggaran lalu lintas yang dilakukan oleh anak. Hal tersebut dapat dilihat pada tabel berikut:

Tabel 1

Jumlah Pelanggaran Lalu Lintas Kendaraan Bermotor yang Dilakukan Oleh Anak di Satlantas Polres Tanjabbar

\begin{tabular}{|c|c|c|c|}
\hline No. & Tahun & Jumlah Pelanggaran dan Jenis pelanggaran & $\begin{array}{c}\text { Proses } \\
\text { Penggenaan } \\
\text { Sanksi }\end{array}$ \\
\hline \multirow[t]{2}{*}{1.} & 2017 & $\begin{array}{l}869 \text { Kasus } \\
\text { - Helm : } 781 \text { (Pasal } 291 \text { Ayat (1) dan (2) jo Pasal } \\
106 \text { Ayat (8) UULAJ) } \\
\text { - Guna Hp : } 21 \text { (Pasal } 283 \text { jo Pasal } 106 \text { Ayat (1) } \\
\text { UULAJ) } \\
\text { - melawan arus : } 67 \text { (Pasal } 287 \text { Ayat (1) jo Pasal } 106 \\
\text { Ayat (4) UULAJ) }\end{array}$ & Ditilang \\
\hline & & $\begin{array}{l}\text { 692 Kasus } \\
\text { - Helm : } 410 \quad \text { (Pasal } 291 \text { Ayat (1) dan (2) jo Pasal } \\
106 \text { Ayat (8) UULAJ) } \\
\text { - Guna Hp : } 105 \text { (Pasal } 283 \text { jo Pasal } 106 \text { Ayat (1) } \\
\text { UULAJ) } \\
\text { - melawan arus : } 177 \text { (Pasal } 287 \text { Ayat (1) jo Pasal } 106 \\
\text { Ayat (4) UULAJ) }\end{array}$ & Teguran \\
\hline \multirow[t]{2}{*}{2.} & 2018 & $\begin{array}{l}\text { 686 Kasus } \\
\text { - Helm : } 611 \text { (Pasal } 291 \text { Ayat (1) dan (2) jo Pasal } 106 \\
\text { Ayat (8) UULAJ) } \\
\text { - Guna Hp : } 17 \text { Pasal } 283 \text { jo Pasal } 106 \text { Ayat (1) } \\
\text { UULAJ) } \\
\text { - Melawan arus : } 58 \text { (Pasal } 287 \text { Ayat (1) jo Pasal } 106 \\
\text { Ayat (4) UULAJ) }\end{array}$ & Ditilang \\
\hline & & $\begin{array}{l}\text { 504 Kasus } \\
\text { - Helm : } 350 \text { (Pasal } 291 \text { Ayat (1) dan (2) jo Pasal } 106 \\
\text { Ayat (8) UULAJ) } \\
\text { - Guna Hp : } 51 \text { (Pasal } 283 \text { jo Pasal } 106 \text { Ayat (1) } \\
\text { UULAJ) } \\
\text { - melawan arus : } 103 \text { (Pasal } 287 \text { Ayat (1) jo Pasal } 106 \\
\text { Ayat (4) UULAJ) }\end{array}$ & Teguran \\
\hline 3. & 2019 & $\begin{array}{l}224 \text { Kasus } \\
\text { - Helm : } 201 \text { (Pasal } 291 \text { Ayat (1) dan (2) jo Pasal } 106 \\
\text { Ayat (8) UULAJ) } \\
\text { - Guna Hp : } 3 \text { (Pasal } 283 \text { jo Pasal } 106 \text { Ayat (1) UULAJ) } \\
\text { - Melawan Arus : } 20 \text { (Pasal } 287 \text { Ayat (1) jo Pasal } 106 \\
\text { Ayat (4) UULAJ) }\end{array}$ & Ditilang \\
\hline
\end{tabular}


201 Kasus

Teguran

- Helm : 51 (Pasal 291 Ayat (1) dan (2) jo Pasal 106

Ayat (8) UULAJ)

- Guna Hp : 104 Pasal 283 jo Pasal 106 Ayat (1)

UULAJ)

- Melawan Arus : 46 (Pasal 287 Ayat (1) jo Pasal 106

Ayat (4) UULAJ)

Sumber Data: Satlantas Polres Tanjabbar

Keterangan:

1. Pasal 106 Ayat (8) Undang-Undang Nomor 22 Tahun 2009 tentang Lalu Lintas dan Angkutan Jalan yakni: "Setiap orang yang mengemudikan sepeda motor dan penumpang sepeda motor wajib mengenakan helm yang memenuhi standar nasional Indonesia.

2. Menggunakan ponsel saat mengendarai mobil pada dasarnya melanggar dua pasal dalam Undang-Undang Nomor 22 tahun 2009 Tentang Lalu-Lintas dan Angkutan Jalan, yakni Pasal 106 yang mewajibkan pengemudi berkendara dengan wajar dan penuh konsentrasi, serta Pasal 283 yang mengatur pidana kurungan paling lama 3 (tiga) bulan dan denda paling banyak 750.000 rupiah bagi para pelanggar.

3. Pasal 283

Setiap orang yang mengemudikan Kendaraan Bermotor di Jalan secara tidak wajar dan melakukan kegiatan lain atau dipengaruhi oleh suatu keadaan yang mengakibatkan gangguan konsentrasi dalam mengemudi di Jalan sebagaimana dimaksud dalam Pasal 106 ayat (1) dipidana dengan pidana kurungan paling lama 3 (tiga) bulan atau denda paling banyak Rp750.000,00 (tujuh ratus lima puluh ribu rupiah).

4. Pasal 287,

Ayat 1: tentang sanksi melanggar aturan perintah / larangan yang dinyatakan dengan rambu lalu lintas atau marka jalan dipidana dengan pidana kurungan paling lama 2 (dua) bulan atau denda paling banyak Rp 500.000

Ayat 2: tentang sanksi melanggar aturan perintah / larangan yang dinyatakan dengan alat pemberi isyarat lalu lintas dipidana dengan pidana kurungan paling lama 2 (dua) bulan atau denda paling banyak Rp 500.000

Ayat 3: tentang sanksi melanggar aturan gerakan lalu lintas atau tata cara berhenti dan parkir dipidana dengan pidana kurungan paling lama 1 (satu) bulan atau denda paling banyak Rp 250.000.

5. Pasal 291

(1) Setiap orang yang mengemudikan Sepeda Motor tidak mengenakan helm standar nasional Indonesia sebagaimana dimaksud dalam Pasal 106 ayat (8) dipidana dengan pidana kurungan paling lama 1 (satu) bulan atau denda paling banyak Rp250.000,00 (dua ratus lima puluh ribu rupiah).

(2) Setiap orang yang mengemudikan Sepeda Motor yang membiarkan penumpangnya tidak mengenakan helm sebagaimana dimaksud dalam Pasal 106 ayat (8) dipidana dengan pidana kurungan paling lama 1 (satu) bulan atau denda paling banyak Rp250.000,00 (dua ratus lima puluh ribu rupiah). 
Berdasarkan tabel di atas, dapatlah diketahui bahwa jumlah pelanggaran lalu lintas kendaraan bermotor yang dilakukan oleh anak di Satlantas Polres Tanjabbar terus terjadi dengan jumlah fluktuatif tiap tahun dari tahun 2017 sebanyak 869 kasus, tahun 2018 sebanyak 686 kasus dan tahun 2019 yang berjumlah 224 kasus. Proses penggenaan sanksi dilakukan dengan mekanisme tilang untuk diajukan ke Pengadilan Negeri Kuala Tungkal. Sedangkan untuk teguran pada tahun 2017 sebanyak 692 kasus, tahun 2018 sebanyak 504 kasus dan tahun 2019 sebanyak 201 kasus.

Hukum pidana Indonesia masih memberikan suatu keringanan penggenaan ancaman hukuman apabila pelaku tindak pidana tersebut masih berusia di bawah 18 tahun atau belum pernah kawin. Undang-Undang Nomor 11 Tahun 2012 tentang Sistem Peradilan Pidana Anak dalam Pasal 79 dan Pasal 81 menentukan bahwa:

Pasal 79:

(1) Pidana pembatasan kebebasan diberlakukan dalam hal Anak melakukan tindak pidana berat atau tindak pidana yang disertai dengan kekerasan.

(2) Pidana pembatasan kebebasan yang dijatuhkan terhadap Anak paling lama $1 / 2$ (satu perdua) dari maksimum pidana penjara yang diancamkan terhadap orang dewasa.

(3) Minimum khusus pidana penjara tidak berlaku terhadap Anak.

(4) Ketentuan mengenai pidana penjara dalam KUHP berlaku juga terhadap Anak sepanjang tidak bertentangan dengan Undang-Undang ini.

Pada kenyataannya walaupun telah dilakukan pelarangan dan pemberian ancaman hukuman, masih ada juga anak yang melakukan pelanggaran lalu lintas.

Pelanggaran lalu lintas oleh anak agar tidak terus berkembang dan pelakunya jera untuk mengulangi perbuatannya maka perlunya dilaksanakan ketentuan hukum pidana yang sebenar-benarnya dengan melarang pelanggaran lalu lintas tersebut dan memidana para pelakunya.

Pemidanaan yang dilakukan tentunya tidak terlepas dari etika tentang hukuman legal yaitu:

1. Hak moral untuk menghukum seseorang didasarkan semata-mata atas kenyataan bahwa ia telah terbukti melakukan suatu kesalahan atau kejahatan.

2. Kewajiban moral untuk menghukum pun secara eksklusif kokoh di atas landasan yang sama.

3. Demi keadilan retributif, maka hukuman harus seimbang dengan bobot kesalahan yang telah dilakukan.

4. Dasar moral pemberian hukuman ialah hukuman merupakan "pemutihan" terhadap kesalahan dan "reaformasi" terhadap hukum yang dilawan, hukuman merupakan pula "hak" dari pelaku kejahatan.

5. Konsekuensi hukuman sebagai pencegahan agar di masa yang akan datang kejahatan terhukum tak akan terulang lagi.

6. Hukuman itu memberikan kepuasan baik kepada si korban maupun kepada orang lain. ${ }^{3}$

Pemidanaan terhadap anak seharusnya tidak sama dengan pemidanaan yang dilakukan terhadap orang dewasa karena kondisi psikologis/kejiwaan dan fisik orang dewasa sangat berbeda dengan anak. Bertalian dengan jenis pidana anak ini, Made Sadhi yang dikutip oleh Bunadi Hidayat mengemukakan:

3 Yong Ohoitimur, Teori Etika Tentang Hukuman Legal, PT Gramedia Pustaka Utama, Jakarta, 1997, hlm. 17-19. 
Sanksi pidana bagi anak adalah:

1. Ditempatkan di pusat sekolah penelitian

2. Perintah penahanan

3. Denda berupa uang

4. Teguran. ${ }^{4}$

Pada Pasal 71 Undang-Undang Sistem Peradilan Pidana Anak ini ditentukan bahwa pidana pokok bagi anak terdiri atas:

a. Pidana peringatan, yakni pidana ringan yang tidak mengakibatkan pembatasan kebebasan anak

b. Pidana dengan syarat:

1). Pembinaan di luar lembaga

2). Pelayanan masyarakat, atau

3). Pengawasan

c. Pelatihan kerja

d. Pembinan dalam lembaga

e. Penjara.

Untuk pidana denda yang tidak bisa dibayarkan akan diganti dengan pidana pelatihan kerja. Dalam Pasal 71 ayat (3) Undang-Undang Sistem Peradilan Pidana Anak ditentukan: "Apabila dalam hukum materiil diancam pidana kumulatif berupa penjara dan denda, pidana denda diganti dengan pelatihan kerja".

Sanksi tindakan yang dapat dikenakan kepada anak meliputi (Pasal 82 UndangUndang Sistem Peradilan Pidana Anak):

a. Pengembalian kepada orang tua/Wali;

b. Penyerahan kepada seseorang;

c. Perawatan di rumah sakit jiwa;

d. Perawatan di LPKS;

e. Kewajiban mengikuti pendidikan formal dan/atau pelatihan yang diadakan oleh pemerintah atau badan swasta;

f. Pencabutan surat izin mengemudi; dan/atau

g. Perbaikan akibat tindak pidana.

Ketentuan mengenai sanksi tindakan tidak dikemukakan secara jelas dan tegas dalam Undang-Undang Nomor 22 Tahun 2009 Tentang Lalu Lintas dan Angkutan jalan sehingga hal ini menimbulkan kerancuan dalam pelaksanaannya khususnya terhadap sanksi tindakan terhadap pelanggaran lalu lintas yang dilakukan oleh anak apakah dikenakan sanksi denda, tilang atau tindakan. Dalam prakteknya pelanggaran lalu lintas yang dilakukan oleh anak tidak selamanya dikenakan tilang seringkali diberikan berupa sanksi tindakan.

Untuk sanksi tindakan termasuk dalam data jumlah pelanggaran lalu lintas kendaraan bermotor yang dilakukan oleh anak di Satlantas Polres Tanjabbar dari tahun 2017 sampai dengan tahun 2019 tetapi tidak dikenakan tilang hanya sanksi teguran. Seharusnya sanksi tindakan yang diberikan sesuai dengan ketentuan Pasal 82 Undang-Undang Sistem Peradilan Pidana Anak.

$4 \quad$ Ibid., hlm. 86. 


\section{B. METODE PENELITIAN}

Metode yang digunakan adalah tipe penelitian yuridis empiris, karena melihat semua peraturan yang berkaitan dengan objek yang diteliti, seperti UU Lalu Lintas dan peraturan lainnya. Selanjutnya melihat penerapan sanksi tindakan terhadap pelanggaran lalu lintas yang dilakukan oleh anak, apakah di terapkan sanksi yang sesuai dengan aturan UU Lalu Lintas.

\section{PEMBAHASAN}

1. PENERAPAN SANKSI TINDAKAN TERHADAP PELANGGARAN LALU LINTAS YANG DILAKUKAN OLEH ANAK DI POLRES TANJUNG JABUNG BARAT

a. Penerapan Sanksi Tindakan Terhadap Pelanggaran Lalu Lintas Yang Dilakukan Oleh Anak Di PolresTanjung Jabung Barat

Berdasarkan hasil penelitian di Polres Tanjung Jabung Barat mengenai penerapan sanksi tindakan terhadap pelanggaran lalu lintas yang dilakukan oleh anak tersebut berhubungan dengan bentuk diskresi kepolisian sebagaimana diatur dalam Undang-Undang Nomor 2 Tahun 2002 Tentang Kepolisian Negara Republik Indonesia, yang menentukan:

Pasal 18

(1) Untuk kepentingan umum pejabat Kepolisian Negara Republik Indonesia dalam melaksanakan tugas dan wewenangnya dapat bertindak menurut penilaiannya sendiri.

(2) Pelaksanaan ketentuan sebagaimana dimaksud dalam ayat (1) hanya dapat dilakukan dalam keadaan yang sangat perlu dengan memperhatikan peraturan perundang-undangan, serta Kode Etik Profesi Kepolisian Negara Republik Indonesia.

Untuk sanksi tindakan termasuk dalam data jumlah pelanggaran lalu lintas kendaraan bermotor yang dilakukan oleh anak di Satlantas Polres Tanjabbar dari tahun 2017 sampai dengan tahun 2019 tetapi tidak dikenakan tilang hanya sanksi teguran. Seharusnya sanksi tindakan yang diberikan sesuai dengan ketentuan Pasal 82 Undang-Undang Sistem Peradilan Pidana Anak. Hal ini seperti diutarakan oleh Iptu Eko Sutoyo yang menyatakan bahwa:

Sanksi tindakan diberikan terhadap anak yang melakukan pelanggaran lalu lintas yang tergolong sebagai pelanggaran ringan seperti tidak memakai helm saat berkendara, menggunakan Hp serta melawan arus lalu lintas. Adapun sanksinya pidana kurungan paling lama 3 (tiga) bulan dan denda paling banyak Rp. 750.000,- bagi para pelanggar. ${ }^{5}$

Satlantas Polres Tanjabbar dalam melakukan penerapan sanksi tindakan terhadap pelanggaran lalu lintas yang dilakukan oleh anak dituntut untuk memahami segala seluk beluk hukum mengenai proses hukum yang terjadi sehingga setiap ada regulasi peraturan perundang-undangan seyogyanyalah seorang anggota Satlantas Polres Tanjabbar mengetahui dan memahaminya secara baik dan benar sehingga apabila terjadi suatu pelanggaran lalu lintas yang dilakukan oleh anak, maka anggota Satlantas Polres Tanjabbar tersebut haruslah mendasarkan tindakannya pada UndangUndang Nomor 2 Tahun 2002 Tentang Kepolisian Negara Republik Indonesia, Undang-

5 Wawancara dengan Iptu Eko Sutoyo, Kasat Lantas Polres Tanjabbar, Kuala Tungkal, 22 Agustus 2020. 
Undang Nomor 22 Tahun 2009 tentang Lalu Lintas dan Angkutan Jalan, UndangUndang Nomor 11 Tahun 2012 tentang Sistem Peradilan Pidana Anak dalam melakukan tindakan dan penerapan sanksi terhadap pelanggaran yang terjadi. Mengenai hal dilakukannya diskresi terhadap sanksi Tindakan kepada anak yang melakukan pelanggaran lalu lintas, menurut Iptu Eko Sutoyo, yang menyatakan bahwa:

Diskresi ini diperbolehkan dilakukan untuk mengantisipasi kekosongan aturan, Hal ini mengingat sanksi Tindakan ini perlu untuk dilakukan, apabila tidak diterapkan akan ada pengulangan pelanggaran tersebut oleh anak tersebut dan orang-orang lainnya. Diskresi ini dilakukan agar terciptanya tertib lalu lintas walaupun pelanggaran tersebut dilakukan oleh anak. ${ }^{6}$

Penerapan sanksi tindakan terhadap pelanggaran lalu lintas yang dilakukan oleh anak tidak bisa dilepaskan dari peran dan fungsi seorang anggota Satlantas Polres Tanjabbar, menurut Iptu Eko Sutoyo, yang menyatakan bahwa:

Dalam menentukan sanksi tindakan terhadap pelanggaran lalu lintas yang dilakukan oleh anak, anggota Satlantas Polres Tanjabbar untuk tiap kejadian harus memperhatikan, keadaan objektif dari pelanggaran yang dilakukan, harus memperhatikan perbuatan dan pembuatnya. Hal-hal apa saja yang dilanggar oleh anak tersebut? kerugian apakah yang ditimbulkan? bagaimana tingkah laku si anak yang menjadi pelanggar? batas antara maksimum dan minimum harus ditetapkan seluas-luasnya sehingga meskipun semua pertanyaan di atas itu dijawab dengan merugikan anak yang menjadi pelanggar, maksimum sanksi tindakan yang biasa itu sudah memadai. ${ }^{7}$

Dalam Criminal Justice System Integrated, penyelesaian tahap akhir suatu tindak pidana memang berada di tangan hakim sebagai pemberi pidana setelah peran jaksa penuntut umum melakukan penuntutan dan kepolisian melakukan penyidikan. Menurut Iptu Eko Sutoyo menyatakan bahwa:

Dalam menjalankan putusan terhadap anak yang melakukan kejahatan/pelanggaran yang menjadi dasar hukumnya adalah Undang Undang Sistem Peradilan Pidana Anak, KUHP dan KUHAP dan faktor yang menjadi pertimbangan apakah anak tersebut dijatuhi pidana penjara atau tidak seperti segi psikologi atau kejiwaan anak tersebut, latar belakang keluarga (seperti ekonomi keluarga), lingkungan dan berat ringannya kejahatan/pelanggaran yang dilakukan oleh anak itu sendiri. ${ }^{8}$

Hakim sebagai seorang penegak hukum terakhir dalam Criminal Justice System Integrated yang melakukan pemeriksaan dan menjatuhkan pidana sudah seharusnya bisa memahami dan mengetahui setiap ketentuan-ketentuan yuridis yang berlaku mengenai kejahatan/pelanggaran dari ketentuan KUHP, KUHAP atau peraturan perundang-undangan lainnya yang bersifat khusus. Dalam menjatuhkan hukuman seharusnya mengacu pada asas "Lex Specialis Derogat Lex Generalis, karena pelaku kejahatan/pelanggaran tersebut dapat dikalsifikasikan sebagai anak nakal sehingga hakim seyogyanyalah dalam menjatuhkan ancaman pidana berdasarkan Undang

6 Wawancara dengan Iptu Eko Sutoyo, Kasat Lantas Polres Tanjabbar, Kuala Tungkal, 18 Februari 2021.

7 Wawancara dengan Iptu Eko Sutoyo, Kasat Lantas Polres Tanjabbar, Kuala Tungkal, 22 Agustus 2020.

8 Wawancara dengan Iptu Eko Sutoyo, Kasat Lantas Polres Tanjabbar, Kuala Tungkal, 22 Agustus 2020. 
Undang Sistem Peradilan Pidana Anak selain adanya kebebasan hakim dalam menjatuhkan hukuman yang didasarkan pada keyakinannya. Tetapi dalam penerapan aturan Undang-Undang Nomor 22 Tahun 2009 Tentang Lalu Lintas dan Angkutan jalan, pihak kepolisian dapat menerapkan sanksi terhadap pelanggaran yang terjadi, khususnya terhadap anak yang melakukan pelanggaran lalu lintas.

Selanjutnya menurut Iptu Eko Sutoyo yang menyatakan bahwa:

Yang menjadi pertimbangan untuk menjatuhkan sanksi tindakan berupa pidana penjara atau diserahkan kepada negara maupun dikembalikan kepada orang tua antara lain bagi anak yang dikembalikan kepada orang tua dengan pertimbangan anak tersebut baru sekali melakukan tindak pidana, masih sekolah, masih bisa dibina oleh keluarganya dan orang tua/wali dalam keadaan mampu dan diyakini dapat membina anak tersebut merupakan kewenangan hakim. Seterusnya untuk anak yang diserahkan kepada negara dengan pertimbangan telah berulang melakukan tindak pidana, tidak dapat dibina oleh keluarganya lagi, orang tua/wali kurang mampu atau tidak diyakini mampu membina anak tersebut dan bagi anak yang dijatuhi pidana penjara antara lain dengan pertimbangan telah berulang kali melakukan tindak pidana, usia telah menjelang dewasa antara 1518 tahun, tindak pidana cukup berat dan dianggap telah layak untuk menjalani pidana. ${ }^{9}$

Iptu Eko Sutoyo menyatakan alasan hakim tidak memberikan sanksi berupa tindakan atau mengembalikan kepada orang tuanya adalah:

Apabila dikembalikan kepada orang tuanya anak itu tidak akan terawat sehingga dikhawatirkan anak itu akan mengulangi lagi perbuatannya, keadaan keluarga yang tidak memungkinkan si anak dikembalikan kepada orang tuanya, mungkin karena keadaan sosial ekonominya yang kurang baik sehingga dengan menjatuhkan sanksi pidana penjara, hakim telah mengusahakan kesejahteraan anak, bahwa ia tidak sanggup untuk menerima atau mendidik anaknya lagi. ${ }^{10}$

Sehingga dalam menjatuhkan pidana seorang hakim hendaknya bertindak secara bijak dalam menilai segala kemungkinan yang terjadi apabila si anak dikenakan ancaman pidana baik itu mengenai lamanya pidana dijalankan atau pemilihan pidana yang dikenakan antara pidana penjara atau diserahkan kepada negara untuk dibina maupun dikembalikan kepada orang tua. Hal ini didasarkan masa depan anak tersebut tanpa mengeyampingkan perasaan keadilan bagi korban tindak pidana yang dilakukan anak tersebut.

Sanksi tindakan yang dapat dikenakan kepada anak seperti yang ditentukan dalam Pasal 82 Undang-Undang Sistem Peradilan Pidana Anak, berupa:

a. Pengembalian kepada orang tua/Wali;

b. Penyerahan kepada seseorang;

c. Perawatan di rumah sakit jiwa;

d. Perawatan di LPKS;

e. Kewajiban mengikuti pendidikan formal dan/atau pelatihan yang diadakan oleh pemerintah atau badan swasta;

f. Pencabutan surat izin mengemudi; dan/atau

g. Perbaikan akibat tindak pidana.

9 Wawancara dengan Iptu Eko Sutoyo, Kasat Lantas Polres Tanjabbar, Kuala Tungkal, 22 Agustus 2020.

10 Wawancara dengan Iptu Eko Sutoyo, Kasat Lantas Polres Tanjabbar, Kuala Tungkal, 22 Agustus 2020. 
Merupakan ranah wewenang hakim, bukanlah bagian wewenang kepolisian dalam hal ini anggota Satlantas Polres Tanjabbar. Hanya untuk jenis pelanggaran lalu lintas tertentu seperti tidak memakai helm saat berkendara, menggunakan Hp serta melawan arus lalu lintas, dapat dikenakan sanksi tindakan oleh anggota Satlantas Polres Tanjabbar. Selain hal tersebut merupakan bentuk diskresi kepolisian sebagaimana diatur dalam Pasal 18 Undang-Undang Nomor 2 Tahun 2002 Tentang Kepolisian Negara Republik Indonesia.

Maksud dan tujuan sanksi tindakan yang diberikan oleh anggota Satlantas Polres Tanjabbar itu sendiri menurut Iptu Eko Sutoyo yaitu: "Untuk mendidik anak tersebut sehingga ia tidak mengulangi lagi perbuatannya dimana ia akan pelanggaran yang dilakukannya bisa membahayakan jiwanya dan orang lain".11

Pertimbangan yang digunakan oleh anggota Satlantas Polres Tanjabbar dalam penerapan sanksi tindakan terhadap pelanggaran lalu lintas yang dilakukan oleh anak bahwa ada 3 (tiga) alternatif yang ditempuh oleh anggota Satlantas Polres Tanjabbar yaitu:

1. Dikembalikan kepada orang tua/wali, pemeliharaannya dengan tanpa suatu hukuman adapun

2. Si pelanggar diserahkan kepada pemerintah untuk mendapat pendidikan dengan tanpa hukuman apapun

3. Dijatuhi pidana atau hukuman berupa sanksi tindakan seperti yang ditentukan dalam Pasal 82 Undang-Undang Sistem Peradilan Pidana Anak ataupun berdasarkan diskresi kepolisian.

Alternatif pertama tidak memerlukan suatu syarat apapun, demikian pula alternatif ketiga. Sedangkan untuk alternatif kedua yaitu anak dapat diserahkan kepada negara untuk mendapat pembinaan/pendidikan/latihan kerja dengan tanpa dihukum, memerlukan syarat-syarat sebagai berikut:

1. Melakukan kejahatan atau salah satu pelanggaran yang termaktub dalam Pasal 45 KUHP

2. Yang bersangkutan adalah residivis

Berdasarkan syarat-syarat tersebut maka faktor-faktor yang mempengaruhi anggota Satlantas Polres Tanjabbar untuk melakukan penerapan sanksi tindakan terhadap pelanggaran lalu lintas yang dilakukan oleh anak, tidak cukup diamati jalur yuridis saja tetapi juga melalui jalur lain, seperti latar belakang si anak, menurut Iptu Eko Sutoyo yang menerangkan bahwa:

1. Pendidikan anak, jenis kelamin

2. Pribadi anak

3. Sikap orang tua anak terhadap si anak ${ }^{12}$

Faktor-faktor tersebut mempengaruhi dalam mengambil keputusan berkaitan dengan Pasal 45 KUHP dan Pasal 82 Undang-Undang Sistem Peradilan Pidana Anak dapat dikemukakan yakni:

11 Wawancara dengan Iptu Eko Sutoyo, Kasat Lantas Polres Tanjabbar, Kuala Tungkal, 22 Agustus 2020.

12 Wawancara dengan Iptu Eko Sutoyo, Kasat Lantas Polres Tanjabbar, Kuala Tungkal, 22 Agustus 2020. 
1. Pendidikan anak, jenis kelamin

Sebagian pelaku kejahatan/pelanggaran yang terbukti bersalah melakukan kejahatan/pelanggaran pernah atau masih bersekolah. Pada waktu anak-anak tersebut harus berurusan dengan pihak yang berwajib karena disangka melakukan kejahatan/pelanggaran si anak sudah tidak bersekolah lagi (putus sekolah). Oleh sebab itu faktor pendidikan anak juga dapat mempengaruhi keputusan dalam mempertimbangkan penempatan si pelaku kejahatan/pelanggaran berkaitan dengan penerapan Pasal 45 KUHP dan Pasal 82 Undang-Undang Sistem Peradilan Pidana Anak. Kembalinya anak kepada orang tua merupakan harapan dari setiap orang tua yang anaknya berurusan dengan pihak yang berwajib.

2. Pribadi anak

Pribadi atau kepribadian seseorang adalah jumlah keseluruhan dari sifat-sifat kejiwaan di bawah pengaruh kehendak sadar dirinya. Sifat-sifat tersebut sudah kelihatan sejak bayi dan cenderung tetap beberapa pendapat mengatakan bahwa karakter bisa menyebabkan kenakalan anak.

3. Sikap orang tua anak terhadap si anak

Kesediaan orang tua/walinya mendidik kembali anak-anaknya mendapat perhatian, orang tua yang menyatakan tidak sanggup lagi mendidik anaknya, memang tidak diberikan kesempatan.

Pidana kurungan dan denda yang dijatuhkan oleh hakim di Pengadilan Negeri Kuala Tungkal terhadap anak yang melakukan pelanggaran lalu lintas tergolong pendek yaitu berkisar yaitu sanksinya pidana kurungan paling lama 3 (tiga) bulan dan denda paling banyak Rp. 750.000,- bagi para pelanggar menimbulkan keraguan apakah dalam kurun waktu tersebut tujuan dari pemidanaan yang akan hanya sebagai pembalasan tetapi juga membina terpidana dapat dicapai dan hal ini dapat berlaku efektif membina terpidana tetapi dapat pula tidak efektif dalam mencapai tujuan pemidanaan tersebut, hal ini tergantung pada anak dan kasus per kasusnya namun diharapkan anak-anak dengan usia yang masih muda dan kualitas pelanggarannya tidak terlalu berat maka akan lebih mudah pula untuk membinanya.

Sehingga dapatlah dikemukakan bahwa di Polres Tanjabbar, dalam penerapan sanksi tindakan terhadap pelanggaran lalu lintas yang dilakukan oleh anak sama halnya dengan orang dewasa yang melakukan pelanggaran, yaitu berpedoman pada pedoman pemidanaan secara umum seperti yang diatur dalam Pasal 52 Rancangan KUHP yaitu:
a. Kesalahan si pembuat
b. Motif dan tujuan melakukan kejahatan/pelanggaran
c. Cara melakukan kejahatan/pelanggaran
d. Sikap batin si pelaku
e. Riwayat hidup dan keadaan sosial ekonomi si pelaku
f. Pengaruh pidana terhadap masa depan si pelaku

Mengenai pelaksanaan penerapan sanksi tindakan terhadap pelanggaran lalu lintas yang dilakukan oleh anak, dapat dikemukakan:

Penerapan sanksi tindakan terhadap pelanggaran lalu lintas yang dilakukan oleh anak, didasarkan pada pertimbangan sebagai berikut: 
1. Bahwa penerapan sanksi tindakan terhadap pelanggaran lalu lintas yang dilakukan oleh anak berupa pidana kurungan paling lama 3 (tiga) bulan dan denda paling banyak Rp. 750.000,- tidak menjamin adanya efek jera terhadap anak yang melakukan pelanggaran lalu lintas.

2. Bahwa terhadap ancaman minimum, baik pidana kurungan dan pidana denda adalah berlaku pula ketentuan terkait diferensiasi tersebut di atas.

3. Bahwa beban psikologis terhadap anak yang menjadi pelanggar lalu lintas, beban psikologis terhadap anak yang menjadi pelanggar lalu lintas, apabila dikenakan pidana kurungan dan pidana denda adalah sangat berat.

4. Bahwa anak yang menjadi pelanggar masih dan tetap ingin mengikuti pendidikan formal di sekolahnya, sehingga apabila dijatuhkan pidana yang bersifat perampasan kemerdekaan, maka akan berpengaruh pada masa depannya.

Bahwa jumlah pelanggaran lalu lintas kendaraan bermotor yang dilakukan oleh anak di Satlantas Polres Tanjabbar terus terjadi dengan jumlah fluktuatif tiap tahun dari tahun 2017 sebanyak 869 kasus, tahun 2018 sebanyak 686 kasus dan tahun 2019 yang berjumlah 224 kasus. Proses penggenaan sanksi dilakukan dengan mekanisme tilang untuk diajukan ke Pengadilan Negeri Kuala Tungkal. Sedangkan untuk teguran pada tahun 2017 sebanyak 692 kasus, tahun 2018 sebanyak 504 kasus dan tahun 2019 sebanyak 201 kasus. Hal ini lebih jelasnya dapat dilihat pada tabel berikut:

Tabel 1

Jumlah Pelanggaran Lalu Lintas Kendaraan Bermotor Yang Dilakukan Oleh Anak dan proses penggenaan sanksi teguran di Satlantas Polres Tanjabbar

\begin{tabular}{|c|c|c|c|}
\hline No. & Tahun & Jumlah Pelanggaran dan Jenis pelanggaran & $\begin{array}{c}\text { Proses Penggenaan } \\
\text { Sanksi }\end{array}$ \\
\hline 1. & 2017 & $\begin{array}{l}\text { 692 Kasus } \\
\text { - Helm : } 410 \\
\text { - Guna Hp : } 105 \\
\text { - melawan arus : } 177\end{array}$ & Teguran \\
\hline 2. & 2018 & $\begin{array}{l}\text { 504 Kasus } \\
\text { - Helm : } 350 \\
\text { - Guna Hp : } 51 \\
\text { - melawan arus : } 103\end{array}$ & Teguran \\
\hline 3. & 2019 & $\begin{array}{l}201 \text { Kasus } \\
\text { - Helm : } 51 \\
\text { - Guna Hp : } 104 \\
\text { - Melawan Arus : } 46\end{array}$ & Teguran \\
\hline
\end{tabular}

Sumber Data: Satlantas Polres Tanjabbar

Berdasarkan tabel di atas, dapat dikemukakan pelanggaran lalu lintas yang dilakukan oleh anak sifatnya fluktuatif (naik turun) setiap tahunnya. Jenis pelanggaran berupa tahun 2017 sebanyak 692 kasus berupa 410 kasus yang tidak menggunakan helm, 105 kasus menggunakan HP saat berkendara dan 177 kasus melawan arus lalu lintas, tahun 2018 sebanyak 504 kasus berupa 350 kasus yang tidak menggunakan helm, 51 kasus menggunakan HP saat berkendara dan 103 kasus melawan arus lalu 
lintas, dan tahun 2019 sebanyak 201 kasus berupa 51 kasus yang tidak menggunakan helm, 104 kasus menggunakan HP saat berkendara dan 46 kasus melawan arus lalu lintas,

Mengenai penerapan sanksi tindakan terhadap pelanggaran lalu lintas yang dilakukan oleh anak dapat dilihat pada tabel berikut:

Tabel 2

Bentuk sanksi tindakan terhadap Pelanggaran Lalu Lintas Kendaraan Bermotor Yang

Dilakukan Oleh Anak dan jumlah pelanggar anak

di Satlantas Polres Tanjabbar

\begin{tabular}{|c|c|c|c|}
\hline No. & Tahun & Bentuk Sanksi Tindakan & $\begin{array}{c}\text { Jumlah Pelanggar } \\
\text { Anak }\end{array}$ \\
\hline \multirow[t]{5}{*}{1.} & \multirow[t]{5}{*}{2017} & 1. Push up, & 223 \\
\hline & & 2. Disuruh baca Pancasila di pinggir jalan, & 39 \\
\hline & & 3. Menyanyikan lagu nasional, & 48 \\
\hline & & $\begin{array}{l}\text { 4. Ada juga dipanggil orang tuanya dan } \\
\text { kemudian membuat surat perjanjian atau } \\
\text { pernyataan tidak mengulangi lagi. }\end{array}$ & 325 \\
\hline & & 5. Mendorong motor sejauh $50 \mathrm{~m}-100 \mathrm{~m}$. & 57 \\
\hline \multirow[t]{5}{*}{2.} & \multirow[t]{5}{*}{2018} & 1. Push up, & 197 \\
\hline & & 2. Disuruh baca Pancasila di pinggir jalan, & 66 \\
\hline & & 3. Menyanyikan lagu nasional, & 59 \\
\hline & & $\begin{array}{l}\text { 4. Ada juga dipanggil orang tuanya dan } \\
\text { kemudian membuat surat perjanjian atau } \\
\text { pernyataan tidak mengulangi lagi. }\end{array}$ & 143 \\
\hline & & 5. Mendorong motor sejauh $50 \mathrm{~m}-100 \mathrm{~m}$. & 39 \\
\hline \multirow[t]{5}{*}{3.} & \multirow[t]{5}{*}{2019} & 1. Push up, & 32 \\
\hline & & 2. Disuruh baca Pancasila di pinggir jalan, & 31 \\
\hline & & 3. Menyanyikan lagu nasional, & 28 \\
\hline & & $\begin{array}{l}\text { 4. Ada juga dipanggil orang tuanya dan } \\
\text { kemudian membuat surat perjanjian atau } \\
\text { pernyataan tidak mengulangi lagi. }\end{array}$ & 83 \\
\hline & & 5. Mendorong motor sejauh $50 \mathrm{~m}-100 \mathrm{~m}$. & 27 \\
\hline
\end{tabular}

Sumber Data: Satlantas Polres Tanjabbar

Berdasarkan tabel di atas, dapat dikemukakan bentuk sanksi tindakan terhadap pelanggaran lalu lintas kendaraan bermotor yang dilakukan oleh anak terbagi atas 5 (lima) bentuk sanksi tindakan. Jumlah pelanggaran lalu lintas yang dikenakan sanksi tindakan tidak dipatok khusus untuk pelanggaran apa saja, bentuk sanksi yang diberikan diserahkan kepada pihak anggota Satlantas Polres Tanjabbar, tetapi pada umumnya sanksi tindakan berupa push up dan dipanggil orang tuanya dan kemudian membuat surat perjanjian atau pernyataan tidak mengulangi lagi yang dominan dilakukan sedangkan sanksi tindakan lainnya merupakan sanksi yang tidak dominan dilakukan. 


\section{b. Kendala Dalam Penerapan Sanksi Tindakan Terhadap Pelanggaran Lalu Lintas Yang Dilakukan Oleh Anak Di PolresTanjung Jabung Barat}

Kendala-kendala Riston P. Sinaga dalam penerapan sanksi tindakan terhadap pelanggaran lalu lintas yang dilakukan oleh anak, yaitu:

1. Kurangnya komitmen dari petugas dalam menertibkan pelanggaran lalu lintas yang dilakukan oleh anak

2. Personil yang dipandang masih kurang sehingga penertiban tidak berlaku efisien dalam pelaksanaannya. ${ }^{13}$

Lebih lanjut Jhon Roy Siregar mengemukakan: "Kendala yang seringkali ditemukan dalam praktek di lapangan yaitu adanya perlawanan dari anak yang melakukan pelanggaran lalu lintas. Dikarenakan usianya yang belum dewasa sehingga belum memahami kepatuhan hukum."14

Maka yang menjadi kendala dalam penerapan sanksi tindakan terhadap pelanggaran lalu lintas yang dilakukan oleh anak di Kabupaten Tanjabbar yaitu:

1. Komitmen dari petugas kurang karena untuk menjalankan penertiban pelaku pelanggar dengan sistem tindakan berupa teguran lebih membutuhkan perhatian dalam hal penanganannya dan pengawasannya

Sudah bukan menjadi rahasia umum lagi, praktek aparat yang bertindak kurang profesional dan proporsional telah mengakar pada dunia penegakan hukum di Indonesia ini. Hal ini terjadi juga dalam kasus pelanggaran lalu lintas, Komitmen dari petugas kurang karena untuk menjalankan penertiban pelaku pelanggar dengan sistem tindakan berupa teguran lebih membutuhkan perhatian dalam hal penanganannya dan pengawasannya. Komitmen ini ditujukan agar petugas melakukan penindakan terhadap anak yang melakukan pelanggaran lalu lintas lebih diprioritaskan untuk diberikan sanksi Tindakan berupa teguran. Tetapi tindakan tersebut tetap memerlukan pola dan mekanisme pengawasan agar sanksi tindakan berupa teguran tersebut tepat sasaran dan efektif.

2. Kurangnya personil sehingga tidak efisian dalam pelaksanaannya

Personil yang ada di Satlantas Polres Tanjabbar masih sangat sedikit dibandingkan dengan luas wilayah dan berbagai macam pelanggaran lalu lintas yang terjadi di PolresTanjabar, sehingga masing-masing personil (petugas) bertanggung jawab dengan tugasnya masing-masing.

Personel Satlantas Polres Tanjabbar pada dasarnya telah dapat melaksanakan fungsi dan tugasnya masing-masing, namun keterbatasan jumlah dan kualitas unsur-unsur polisi lalu lantas bila dihadapkan dengan luas daerah yang menjadi wewenang dan tanggung jawabnya dalam melaksanakan tugasnya.

Jumlah personel Satlantas Polres Tanjabbar yang melaksanakan fungsi dan tugasnya sebagai penindakan terhadap pelanggaran lalu lintas ini sebanyak 15 (lima belas) orang, yang terdiri dari:

13 Wawancara dengan Riston P. Sinaga, Anggota SatLantas Polres Tanjabbar, Kuala Tungkal, 24 Agustus 2020.

14 Wawancara dengan Jhon Roy Siregar, Anggota SatLantas Polres Tanjabbar, Kuala Tungkal, 24 Agustus 2020. 
a) Perwira pertama sebanyak 1 (satu) orang

b) Bintara sebanyak 14 (empat belas) orang

Artinya, keterbatasan personel untuk penindakan terhadap pelanggaran lalu lintas pun masih terbatas.

3. Adanya sikap perlawanan dari pelanggar dikarenakan usianya yang belum dewasa sehingga belum memahami kepatuhan hukum

Dalam hal penerapan sanksi tindakan terhadap pelanggaran lalu lintas yang dilakukan oleh anak di Kabupaten Tanjabbar, data di lapangan menunjukkan bahwa kesadaran hukum masyarakat yang menjadi pelanggar masih tergolong rendah.

4. Sulitnya menghadirkan orang tua anak yang melakukan pelanggaran lalu lintas

Hal ini terjadi pelanggaran yang dilakukan anak tidak diketahui oleh orang tuanya. Kejadian pelanggaran di waktu orang tua anak lagi bekerja atau tidak berada di tempat kejadian pelanggaran tersebut sehingga tidak bisa dihadirkan. Jangka waktu yang relatif pendek untuk menindaklanjuti setiap pelanggaran menimbulkan keadaan bahwa aparat harus mengenakan sanksi Tindakan tanpa ada pemberitahuan atau sepengetahuan orang tua anak yang melakukan pelanggaran.

\section{SIMPULAN}

Bentuk sanksi tindakan terhadap pelanggaran lalu lintas kendaraan bermotor yang dilakukan oleh anak di Polres Tanjung Jabung Barat terbagi atas 5 (lima) bentuk sanksi Tindakan yaitu Push up, disuruh baca Pancasila di pinggir jalan, menyanyikan lagu nasional, ada juga dipanggil orang tuanya dan kemudian membuat surat perjanjian atau pernyataan tidak mengulangi lagi dan mendorong motor sejauh $50 \mathrm{~m}$ $100 \mathrm{~m}$. Jumlah pelanggaran lalu lintas yang dikenakan sanksi tindakan tidak dipatok khusus untuk pelanggaran apa saja, bentuk sanksi yang diberikan diserahkan kepada pihak anggota Satlantas Polres Tanjabbar, tetapi pada umumnya sanksi tindakan berupa push up dan dipanggil orang tuanya dan kemudian membuat surat perjanjian atau pernyataan tidak mengulangi lagi yang dominan dilakukan sedangkan sanksi tindakan lainnya merupakan sanksi yang tidak dominan dilakukan.

Kendala dalam penerapan sanksi tindakan terhadap pelanggaran lalu lintas yang dilakukan oleh anak di Polres Tanjung Jabung Barat yaitu komitmen dari petugas kurang karena untuk menjalankan penertiban pelaku pelanggar dengan sistem tindakan berupa teguran lebih membutuhkan perhatian dalam hal penanganannya dan pengawasannya, kurangnya personil sehingga tidak efisian dalam pelaksanaannya dan Adanya sikap perlawanan dari pelanggar dikarenakan usianya yang belum dewasa sehingga belum memahami kepatuhan hukum selain itu sulitnya menghadirkan orang tua anak yang melakukan pelanggaran tersebut. Penerapannya memerlukan kebijakan dan SOP yang harus dibakukan dulu melalui regulasi peraturan perundang-undangan. 


\section{DAFTAR PUSTAKA}

\section{Dokumen Hukum}

Republik Indonesia. Kitab Undang Undang Hukum Pidana.

. Undang Undang Tentang Lalu Lintas dan Angkutan Jalan. UU Nomor

22 Tahun 2009. LNRI Tahun 2009 Nomor 96, TLNRI Nomor 5025.

.Undang-Undang Tentang Sistem Peradilan Pidana Anak. UU Nomor 11 Tahun 2012. LNRI Tahun 2012 Nomor 153, TLNRI Nomor 5332.

\section{Buku}

Arif, Barda Nawawi. Bunga Rampai Kebijakan Hukum Pidana, Citra Aditya Bakti. Bandung, 1996.

Nasution, Bahder Johan. Metode Penelitian Ilmu Hukum. Bandung: Penerbit Buku CV. Mandar Maju, 2008.

Hasoeprapto, Hartono. Pengantar Tata Hukum Indonesia. Yogyakarta: Penerbit Buku Liberty, Yogyakarta, 1998.

Hidayat, Bunadi. Pemidanaan Anak di Bawah Umur. Bandung: Penerbit Buku Alumni, 2010.

Loqman, Loeby. Pidana dan Pemidanaan. Jakarta: Penerbit Buku Datacom, 2001.

Mulyadi, Lilik. Putusan Hakim dalam Hukum Acara Pidana: Teori, Praktik, Tehnik Penyusunan dan Permasalahannya. Bandung: Penerbit Buku Citra Adtya Bakti, 2010.

Ohoitimur, Yong. Teori Etika Tentang Hukuman Legal. Jakarta: Penerbit Buku PT Gramedia Pustaka Utama, 1997.

Marzuki, Peter Mahmud. Penelitian Hukum, Jakarta: Penerbit Buku Kencana, 2008.

Sholehuddin, M. Sistem Sanksi Dalam Hukum Pidana. Jakarta: Penerbit Buku Raja Grafindo Persada, 2004.

Tim Penyusun. Buku Panduan Fakultas Hukum Universitas Jambi Tahun Akademis 2009/2010. Fakultas Hukum Universitas Jambi, Jambi, 2009.

Jurnal

Nasution, Bahder Johan. "Kajian Filosofis Tentang Konsep Keadilan Dari Pemikiran Klasik Sampai Pemikiran Modern", Jurnal Yustisia, Vol. 3 No.2, (2014) . https://jurnal.uns.ac.id/yustisia/article/view/11106/9938.

Wahyudi Dheny. "Keseimbangan Perlindungan Hukum Terhadap Pelaku Dan Korban Tindak Pidana Dalam Kerangka Restorative Justice", Forum Akademika, Vol. 25

No.1,

(2014).

http://online-

journal.unja.ac.id/index.php/ForAk/article/view/2164. 
Hafrida. "Analisis Putusan Hakim Pengadilan Negeri Jambi Terhadap Pengguna/ Pemakai Narkotika Dalam Perspektif Penanggulangan Tindak Pidana Narkotika Di Kota Jambi", Jurnal Penelitian Universitas Jambi Seri Humaniora, Vol. 16, No.

(2014)

https://www.neliti.com/id/publications/43461/analisis-putusan-hakimpengadilan-negeri-jambi-terhadap-pengguna-pemakai-narkoti

Haryadi. "Tinjauan Yuridis Perumusan Sanksi Pidana Bagi Pelaku Tindak Pidana Korupsi Menurut Undang-Undang No. 31 Tahun 1999 Jo. Undang-undang No. 20 Tahun 2001 Dalam Perspektif Tujuan Pemidanaan", Jurnal Ilmu Hukum Universitas Jambi, Vol. 16, No. 1, (2014). https://media.neliti.com/media/publications/43288-ID-tinjauan-yuridisperumusan-sanksi-pidana-bagi-pelaku-tindak-pidana-korupsi-menur.pdf.

Usman dan Andi Najemi. "Mediasi Penal di Indonesia: Keadilan, Kemanfaatan, dan Kepastian Hukumnya”, Undang: Jurnal Hukum, Vol. 1 No. 1, (2018). https://jurnal.hukumonline.com/a/5cb49c0701fb73000fce15bd/mediasipenal-di-indonesia. 